\title{
Wybrane aspekty ograniczenia obrotu nieruchomościami rolnymi w prawie polskim w kontekście unijnej zasady swobody przepływu kapitału
}

\section{Wstęp}

Z uwagi na zjawiska ekonomiczne zachodzące na rynku nieruchomości rolnych oraz na znaczenie nieruchomości rolnych dla bezpieczeństwa żywnościowego w wielu państwach członkowskich Unii Europejskiej wprowadzono regulacje prawne ograniczające obrót tymi nieruchomościami. W przypadku państw ,nowej” Unii wiązało się to z zakończeniem okresów przejściowych przewidzianych w traktatach akcesyjnych, które dopuszczały odstępstwa od zasady swobodnego przepływu kapitału w przypadku nabywania nieruchomości rolnych ${ }^{1}$. Polski prawodawca także zdecydował się na nowelizację ustawy z 11 kwietnia 2003 r. o kształtowaniu ustroju rolnego ${ }^{2}$ po zakończeniu okresu przejściowego przewidzianego w załączniku $\mathrm{XII}^{3}$ do

\footnotetext{
* Uniwersytet Warszawski.
}

${ }^{1}$ Przykładowo dla Bułgarii i Rumunii okres przejściowy obowiązywał do 1 stycznia 2014 r., dla Litwy, Łotwy, Węgier i Słowacji do 1 maja 2014 r., a dla Polski do 1 maja 2016 r.

${ }^{2}$ Dz. U. z 2018 r., poz. 1405 ze zm. [dalej: u.k.u.r.].

${ }^{3}$ W pkt 4 przywołanego załącznika XII, zatytułowanym „Swobodny przepływ kapitału”, w ust. 2 dopuszczono możliwość utrzymania przez Polskę w mocy, przez okres 12 lat od dnia przystąpienia do UE (tj. do 30 kwietnia 2016 r.), zasad przewidzianych w ustawie z 24 marca 1920 r. o nabywaniu nieruchomości przez cudzoziemców, także w odniesieniu do nabywania nieruchomości rolnych i leśnych przez obywateli innych państw członkowskich i obywateli państw będących stronami Porozumienia o Europejskim Obszarze Gospodarczym (EOG). 
aktu dotyczącego warunków przystąpienia do $\mathrm{UE}^{4}$. Ustawą z 14 kwietnia 2016 r. o wstrzymaniu sprzedaży nieruchomości Zasobu Własności Rolnej Skarbu Państwa oraz o zmianie niektórych ustaw 30 kwietnia 2016 r. wprowadzone zostały do ustawy o kształtowaniu ustroju rolnego nowe instrumenty ograniczające obrót nieruchomościami rolnymi w Polsce. Wprowadzenie tych zmian spotkało się jednak z krytyką doktryny i praktyki, dlatego ustawą z 26 kwietnia 2019 r. o zmianie ustawy o kształtowaniu ustroju rolnego oraz niektórych innych ustaw, która weszła w życie 25 czerwca 2019 r., wprowadzono nowelizację łagodzącą rygoryzm wcześniejszych rozwiązań.

Jako podstawową zasadę przyjęto, że nieruchomości rolne mogą być nabywane przez rolników indywidualnych (art. 2a u.k.u.r.), lecz przewidziano szereg wyjątków wynikających wprost z ustawy (tzw. wyjątki ustawowe, które można podzielić na podmiotowe, przedmiotowe i obszarowe) oraz dopuszczono wyjątki polegające na możliwości uzyskania indywidualnej zgody dyrektora generalnego Krajowego Ośrodka Wsparcia Rolnictwa (KOWR) na nabycie nieruchomości rolnej (tzw. wyjątki indywidualne). Ponadto wprowadzono zasadę, że nabywca nieruchomości rolnej jest zobowiązany prowadzić gospodarstwo rolne, w skład którego weszła nabyta nieruchomość rolna, przez okres co najmniej 5 lat od dnia nabycia przez niego tej nieruchomości, a w przypadku osoby fizycznej - prowadzić to gospodarstwo osobiście oraz w tym okresie nie może zbyć nabytej nieruchomości ani oddać jej w posiadanie (art. 2a u.k.u.r.), przy czym i w tym przypadku przewidziano szereg wyjątków.

Warto zaznaczyć, że już przed tą nowelizacją w ustawie o kształtowaniu ustroju rolnego były przewidziane instrumenty ograniczające obrót

${ }^{4}$ Załącznik XII do Aktu dotyczącego warunków przystąpienia Republiki Czeskiej, Republiki Estońskiej, Republiki Cypryjskiej, Republiki Łotewskiej, Republiki Litewskiej, Republiki Węgierskiej, Republiki Malty, Rzeczypospolitej Polskiej, Republiki Słowenii i Republiki Słowackiej oraz dostosowań w Traktatach stanowiących podstawę Unii Europejskiej, który na mocy art. 1 ust. 2 Traktatu z 16 kwietnia 2003 r. podpisanego w Atenach między Królestwem Belgii, Królestwem Danii, Republiką Federalną Niemiec, Republiką Grecką, Królestwem Hiszpanii, Republiką Francuską, Irlandią, Republiką Włoską, Wielkim Księstwem Luksemburga, Królestwem Niderlandów, Republiką Austrii, Republiką Portugalską, Republiką Finlandii, Królestwem Szwecji, Zjednoczonym Królestwem Wielkiej Brytanii i Irlandii Północnej (państwami członkowskimi Unii Europejskiej) a Republiką Czeską, Republiką Estońską, Republiką Cypryjską, Republiką Łotewską, Republiką Litewską, Republiką Węgierską, Republiką Malty, Rzecząpospolitą Polską, Republiką Słowenii, Republiką Słowacką dotyczący przystąpienia Republiki Czeskiej, Republiki Estońskiej, Republiki Cypryjskiej, Republiki Łotewskiej, Republiki Litewskiej, Republiki Węgierskiej, Republiki Malty, Rzeczypospolitej Polskiej, Republiki Słowenii i Republiki Słowackiej do Unii Europejskiej (Dz. Urz. UE L 236 z 23.09.2003, s. 875).

${ }^{5}$ Dz. U. z 2016 r., poz. 585. 
nieruchomościami rolnymi, takie jak prawo pierwokupu i prawo nabycia przysługujące KOWR (wcześniej Agencji Nieruchomości Rolnych).

Zbieżność wprowadzenia dodatkowych ograniczeń w obrocie nieruchomościami rolnymi z upływem okresów przejściowych, podczas których ograniczona była swoboda przepływu kapitału, prowadzi do pytania, czy ograniczenia te nie naruszają prawa unijnego, do którego przestrzegania Polska zobowiązała się, przystępując do Unii Europejskiej (warto zaznaczyć, że samo uchwalenie ustawy o kształtowaniu ustroju rolnego też było związane z wejściem Polski do Unii Europejskiej, a ustawa została przyjęta w niezwykle krótkim czasie i opublikowana na dzień przed podpisaniem traktatu o przystąpieniu).

Celem rozważań jest dokonanie oceny dopuszczalności ograniczeń w obrocie nieruchomościami rolnymi uregulowanych w ustawie o kształtowaniu ustroju rolnego w kontekście unijnej zasady swobody przepływu kapitału.

\section{Przesłanki wprowadzenia ograniczeń w obrocie nieruchomościami rolnymi}

Nieruchomość rolna jest jednym z rodzajów nieruchomości w ujęciu cywilnoprawnym, a zatem pozostaje $\mathrm{w}$ kręgu zainteresowania prawa cywilnego. Specyfika nieruchomości rolnych polega na tym, że obejmują one obszar ziemi nadający się do prowadzenia działalności rolniczej i stanowiący kluczowy czynnik produkcji rolnej. Bez obszarów ziemi działalność rolnicza nie może być prowadzona ${ }^{6}$. Do cech wyróżniających ziemię jako czynnik produkcji, a zatem charakteryzujących także nieruchomości nadające się do prowadzenia działalności rolniczej, należy zaliczyć: ich ograniczony zasób (niepomnażalność), gdyż człowiek nie potrafi powiększyć powierzchni ziemi, jak również nieprzenoszalność ${ }^{7}$. Ponadto prowadzona na tych nieruchomościach działalność rolnicza jest niezbędna do wytwarzania produktów rolnych, w tym żywności, której brak lub niedobór stanowi zagrożenie dla zdrowia i życia człowieka. Te szczególne cechy ziemi stanowią wystarczający argument za stworzeniem szczególnej regulacji dotyczącej nieruchomości rolnych.

Nie można też pominąć zjawisk ekonomicznych i klimatycznych, jakie zachodzą na świecie, w tym w UE. Nieruchomości rolne, zwłaszcza w krajach, gdzie ceny nieruchomości są dość niskie, stały się przedmiotem

${ }^{6}$ F. Kapusta, Ziemia w rolnictwie polskim, ,Zeszyty Naukowe Uniwersytetu Przyrodniczego we Wrocławiu. Rolnictwo" CVII N, 2013, nr 596, s. 39.

${ }^{7}$ Ibidem, s. 40-41. 
zainteresowania inwestorów traktujących nabywanie ich jako lokatę kapitału, co spowodowało wzrost popytu na ziemię rolną i związany z tym wzrost $\mathrm{cen}^{8}$. Powodem zwiększonego zainteresowania gruntami rolnymi w Unii Europejskiej było przystąpienie do niej w 2004 r. nowych państw, w których ceny nieruchomości były stosunkowo niskie ${ }^{9}$, a dynamika wzrostu cen była większa przy znacznie niższych kosztach transakcyjnych ${ }^{10}$. Innym powodem był obowiązujący w państwach Unii Europejskiej system płatności bezpośrednich powiązanych z posiadaniem gruntów rolnych oraz możliwość uzyskania różnych form pomocy w ramach tzw. drugiego filara Wspólnej Polityki Rolnej (tj. przewidzianych w Programie Rozwoju Obszarów Wiejskich), przy spełnieniu dodatkowych, nie zawsze trudnych wymogów ${ }^{11}$. Wzrost popytu na nieruchomości rolne wśród inwestorów niebędących rolnikami i związany z tym wzrost cen nieruchomości rolnych stanowi ograniczenie dostępności tych nieruchomości dla rolników, zwłaszcza rolników indywidualnych niedysponujących wystarczającym kapitałem, a w konsekwencji wpływa na bezpieczeństwo żywnościowe.

O znaczeniu nieruchomości rolnych decydują również zjawiska klimatyczne. Wynikające ze zmian klimatu stopniowe zmiany średnich temperatur i opadów deszczu wpływają na przydatność gruntów na różne rodzaje upraw i pastwisk - zmiany te mogą skutkować np. pogorszeniem, a nawet zmniejszeniem areału gruntów ornych ze względu na wzrost jałowości gruntów, zubożenie wód gruntowych i podniesienie poziomu morza ${ }^{12}$.

${ }^{8}$ W latach 2004-2014 lokata kapitału w grunty rolne należała do najbardziej dochodowych, co było szczególnie widoczne w państwach, które przystąpiły do UE w 2004 i 2007 r. Zob. S. Prokurat, Ekonomiczne i prawne aspekty obrotu ziemia w Polsce na tle rynku europejskiego, Acta Universitatis Wratislaviensis” No. 3807, „Ekonomia. Wroclaw Economic Review” 2017, nr 23/3, s. 139 .

9 Przykładowo w 2015 r. średnia cena 1 ha gruntów rolnych w państwach „starej” Unii wynosiła: w Holandii 55500 EUR, w Belgii 33300 EUR, w Danii 23417 EUR, w Niemczech stare landy 29911 EUR, nowe landy - 14197 EUR, Włochy 19854 EUR, z kolei w państwach „nowej” Unii: w Polsce 9200 EUR, w Rumunii i na Słowacji 4500 EUR, w Bułgarii 3743 EUR, na Węgrzech 3300 EUR, na Łotwie 2500 EUR. Zob. A. Sikorska (red.), Rynek ziemi rolniczej. Stan i perspektywy, seria „Analizy rynkowe” nr 19, Warszawa 2016, s. 54.

${ }^{10}$ S. Prokurat, Ekonomiczne i prawne aspekty..., s. 140. Na przestrzeni lat cena ziemi rolnej na świecie stale rosła, np. w latach 2002-2016 wzrost cen w Rumunii wyniósł 2332,1\%, w Polsce 1021,5\%, na Węgrzech 819,1\%, natomiast w Niemczech 176,4\%, w Wielkiej Brytanii 248,8\%, a we Francji 83,2\%. Poza Europą wzrost ten wyniósł: w USA 157,2\%, w Argentynie 621\%, a w Australii 496,3\%. Zob. Informacja o wynikach kontroli „Obrót nieruchomościami rolnymi” KRR 430.006.2018, Nr ewid. 172/2018/P/18/042/KRR, NIK, Warszawa 2019, s. 7.

${ }^{11}$ P. Wojciechowski, Pojęcie nieruchomości rolnej, w: M. Korzycka (red.), Instytucje prawa rolnego, Warszawa 2019, s. 146; S. Prokurat, Ekonomiczne i prawne aspekty..., s. 138 i 142.

${ }^{12}$ Climate change and food security: a framework document, FAO, Rome 2008, http://www. fao.org/forestry/15538-079b31d45081fe9c3dbc6ff34de4807e4.pdf, s. 12 [dostęp: 25.07.2020]. 
Na szczególny charakter gruntów rolnych zwróciły uwagę instytucje unij$n^{13}$ oraz Organizacja Narodów Zjednoczonych ${ }^{14}$. W dokumentach unijnych zapisano m.in., że grunty rolne mają kluczowe znaczenie dla bezpieczeństwa żywnościowego, głównie dlatego że są zasobem ograniczonym, a na niemal połowie terytorium UE są narażone na wykorzystanie pozarolnicze ${ }^{15}$. Za zjawisko niekorzystne uznano ponadto nadmierną koncentrację gruntów ${ }^{16}$. Zwrócono także uwagę, że ziemia jest z jednej strony własnością, a z drugiej dobrem publicznym i podlega zobowiązaniom społecznym ${ }^{17}$. Poza tym ok. 20\% europejskich użytków rolnych jest już dotknięte skutkami zmiany klimatu oraz erozji gleby pod wpływem wody i wiatru, a także nieprofesjonalnego gospodarowania, zaś w wyniku globalnego ocieplenia niektóre regiony UE, szczególnie w południowej Europie, są narażone na susze i inne ekstremalne zjawiska pogodowe, co spowoduje pogorszenie jakości gleby i ograniczy dostępność gruntów wysokiej jakości i gruntów nadających się do użytkowania w rolnictwie ${ }^{18}$. Również FAO (Organizacja Narodów Zjednoczonych do spraw Wyżywienia i Rolnictwa) podkreśla znaczenie gruntów dla osiągania celów w zakresie praw człowieka, bezpieczeństwa żywnościowego, eliminacji ubóstwa, zapewnienia stałych środków utrzymania, stabilności społecznej, bezpieczeństwa mieszkaniowego, rozwoju obszarów wiejskich oraz rozwoju społeczno-gospodarczego ${ }^{19}$.

Słusznie podkreśla się w literaturze, że choć ratio legis wydania ustawy o kształtowaniu ustroju rolnego było wprowadzenie kontroli nabywania gruntów rolnych przez obywateli polskich (która po 1990 r. praktycznie nie istniała), to w związku z przystąpieniem Polski do Unii Europejskiej chciano

${ }^{13}$ Komunikat wyjaśniający Komisji w sprawie nabywania gruntów rolnych i prawa Unii Europejskiej (Dz. Urz. C-350 z 18.10.2017, s. 5); Przyjęte przez Parlament Europejski sprawozdanie w sprawie aktualnego stanu koncentracji gruntów rolnych w UE: jak ułatwić rolnikom dostęp do gruntów?, 2016/2141(INI); Opinia Europejskiego Komitetu Ekonomiczno-Społecznego z 21 stycznia 2015 r. w sprawie „Masowy wykup gruntów rolnych - dzwonek alarmowy dla Europy i zagrożenie dla rolnictwa rodzinnego" (opinia z inicjatywy własnej).

${ }^{14}$ Voluntary Guidelines on the Responsible Governance of Tenure of Land, Fisheries and Forests in the Context of National Food Security, http://www.fao.org/docrep/016/i2801e/i2801e. pdf [dostęp: 25.07.2020].

${ }^{15}$ Komunikat wyjaśniający Komisji..., s. 5.

${ }^{16}$ W 2013 r. zaledwie 3,1\% gospodarstw w UE-27 kontrolowało 52,2\% powierzchni użytków rolnych w Europie, natomiast 76,2\% gospodarstw posiadało jedynie 11,2\% gruntów rolnych. Zob. sprawozdanie w sprawie aktualnego stanu koncentracji gruntów..., pkt A.

17 Ibidem, pkt G.

${ }^{18}$ Rezolucja Parlamentu Europejskiego z 27 kwietnia 2017 r. w sprawie aktualnego stanu koncentracji gruntów rolnych w UE: jak ułatwić rolnikom dostęp do gruntów?, 2016/2141(INI) (Dz. Urz. UE C-298 z 2018 r., s. 112), pkt S.

${ }_{19}$ Voluntary Guidelines on the Responsible Governance..., s. 6. 
ją stosować także wobec obywateli innych państw UE, którzy mogą nabywać grunty na takich samych zasadach jak obywatele polscy (zatem rzeczywistym celem ustawy była ochrona gruntów rolnych przed nabywaniem ich przez cudzoziemców ${ }^{20}$. Także nowelizacja dokonana ustawą o wstrzymaniu sprzedaży nieruchomości Zasobu Własności Rolnej Skarbu Państwa oraz o zmianie niektórych ustaw w istocie służy zabezpieczeniu przed nabywaniem nieruchomości rolnych przez obywateli najbogatszych państw członkowskich Unii Europejskiej, ale i polskich obywateli dysponujących kapitałem, lecz niezainteresowanych prowadzeniem działalności rolniczej. Biorąc jednak pod uwagę zjawiska ekonomiczne i klimatyczne, jakie obecnie zachodzą na świecie, taki rzeczywisty cel wprowadzenia przepisów ograniczających obrót nieruchomościami rolnymi stanowi jeden z elementów kształtowania ustroju rolnego i jest usprawiedliwiony.

\section{Przepisy prawa UE wpływające na dopuszczalny zakres regulacji krajowej obrotu nieruchomościami rolnymi}

Od dnia przystąpienia do Unii Europejskiej Polska związana jest głównie postanowieniami traktatów założycielskich i traktatu akcesyjnego. Warto wskazać przede wszystkim na art. 345 TFUE, odnoszący się wprost do prawa własności, zgodnie z którym „Traktaty nie przesądzają w niczym zasad prawa własności w państwach członkowskich”. Wyraża on zasadę neutralności traktatów wobec zasad prawa własności w państwach członkowskich. W orzecznictwie TSUE wyjaśniono jednak, że neutralność ta nie skutkuje tym, iż przepisy krajowe regulujące nabycie własności rolnej nie podlegają podstawowym zasadom prawa Unii, w szczególności zasadzie niedyskryminacji, swobodzie działalności gospodarczej oraz swobodzie przepływu kapitału ${ }^{21}$. Państwa członkowskie stosownie do przywołanego

${ }^{20}$ A. Lichorowicz, Regulacja obrotu gruntami rolnymi wedlug ustawy o ksztaltowaniu ustroju rolnego na tle ustawodawstwa agrarnego Europy Zachodniej, „Studia Iuridica Agraria” 2005, t. IV, s. 28; S. Prutis, Ksztaltowanie ustroju rolnego-potrzeba nowej regulacji ustawowej, „Studia Iuridica Agraria” 2005, t. V, s. 170 i 182. Na obawę przed zakupem nieruchomości rolnych przez cudzoziemców zwracają uwagę także inni autorzy: K. Stefańska, Pojęcie gospodarstwa rodzinnego w ustawie o kształtowaniu ustroju rolnego, „Studia Iuridica Agraria” 2005, t. V, s. 189; J. Bieluk, Ustawa o ksztaltowaniu ustroju rolnego. Komentarz, Warszawa 2016, s. 225; P. Wojciechowski, Pojęcie rolnika, w: M. Korzycka (red.), Instytucje..., s. 284.

${ }^{21}$ Wyroki TSUE: z 6 marca 2018 r. w sprawach C-52/16 i C-113/16, SEGRO i Horváth, ECLI: EU:C:2018:157, pkt 51; z 6 listopada 1984 r. w sprawie 182/83, Fearon, EU:C:1984:335, pkt 7; z 15 maja 2003 r. w sprawie C-300/01, Salzmann, ECLI:EU:C:2003:283, pkt 39; z 23 września 
art. 345 TFUE mają zatem uprawnienia do ustanowienia reżimu prawnego nabywania własności gruntów przewidującego szczególne środki mające zastosowanie do transakcji dotyczących gruntów rolnych i leśnych, jednak reżim taki podlega w szczególności zasadom niedyskryminacji i swobodzie przepływu kapitału ${ }^{22}$. Jak zauważa się w doktrynie, postanowienia TFUE nie wpływają na istotę prawa własności, mogą jednak znacząco ingerować w sposób korzystania (wykonywania) z tego prawa ${ }^{23}$.

Dla obrotu nieruchomościami rolnymi podstawowe znaczenie ma zatem art. 63 TFUE kształtujący jedną z podstawowych swobód traktatowych, tj. swobodny przepływ kapitału. Zgodnie z nią zakazane są wszelkie ograniczenia w przepływie kapitału pomiędzy państwami członkowskimi oraz między państwami członkowskimi a państwami trzecimi. Swoboda przepływu kapitału - wraz ze swobodą przepływu osób, swobodą przepływu towarów i swobodą przepływu usług - stanowi element rynku wewnętrznego UE. Samo pojęcie swobodnego przepływu kapitału nie zostało zdefiniowane w traktacie. Istotna dla jego wykładni jest nomenklatura przepływów kapitału stosowana w załączniku I do nieobowiązującej już dyrektywy 88/36124. Jak zaznacza się w orzecznictwie TSUE, nomenklatura ta ma walor instrukcji dla zdefiniowania pojęcia przepływu kapitału ${ }^{25}$. W doktrynie, na podstawie aktów prawa pochodnego oraz orzecznictwa TSUE, przepływ kapitału zdefiniowany został jako, ,jednostronne przeniesienie wartości majątkowych w formie pieniężnej (np. środków płatniczych, kredytów, papierów wartościowych) lub

2003 r. w sprawie C-452/01, Ospelt i Schlössle Weissenberg, EU:C:2003:493, pkt 24; z 22 października 2013 r. w sprawach od C-105/12 do C-107/12, Essent i in., EU:C:2013:677, pkt 29 i 36.

${ }^{22}$ Wyroki TSUE: z 6 marca 2018 r. w sprawach C-52/16 i C-113/16, SEGRO i Horváth, ECLI:EU:C:2018:157, pkt 51; z 23 września 2003 r. w sprawie C-452/01, Ospelt i Schlössle Weissenberg, EU:C:2003:493, pkt 24. Szerokie omówienie orzecznictwa w odniesieniu do stosowania art. 345 TFUE: A. Jurcewicz, P. Popardowski, Własność w ujęciu prawa polskiego i prawa UE, „Studia Iuridica Agraria” 2011, t. IX, s. 142-146.

${ }^{23}$ A. Jurcewicz, P. Popardowski, Własność w ujęciu prawa..., s. 142; B. Jeżyńska, R. Pastuszko, Ramy prawne obrotu nieruchomościami rolnymi po 2016 roku, Opinie i Ekspertyzy, Kancelaria Senatu, Warszawa 2012, s. 12.

${ }^{24}$ B. Jeżyńska, R. Pastuszko, Ramy prawne obrotu..., s. 16.

${ }^{25}$ Wyroki TSUE: z 21 maja 2019 r. w sprawie C-235/17, Komisja v. Węgry, ECLI: EU:C:2019:432, pkt 54; z 6 marca 2018 r. w sprawach C-52/16 i C-113/16, SEGRO i Horváth, ECLI:EU:C:2018:157, pkt 56; z 28 października 2010 r. w sprawie C-72/09, Rimbaud, ECLI: EU:C:2010:645, pkt 17; podobnie wyroki: z 16 marca 1999 r. w sprawie C-222/97 Trummer i Mayer, ECLI:EU:C:1999:143, pkt 21; z 11 stycznia 2001 r. w sprawie C-464/98 Stefan, ECLI: EU:C:2001:9, pkt 5; z 5 marca 2002 r. w sprawach połączonych C-515/99, od C-519/99 do C-524/99 i od C-526/99 do C-540/99, Reisch i in., ECLI:EU:C:2002:135, pkt 30; z 14 września 2006 r. w sprawie C-386/04, Centro di Musicologia Walter Stauffer, ECLI:EU:C:2006:568, pkt 22. Zob. też: M. Mataczyński, w: A. Wróbel (red.), Traktat o funkcjonowaniu Unii Europejskiej. Komentarz, t. 1, Warszawa 2012, s. 986. 
rzeczowej (np. udziałów w spółce, nieruchomości) w celu inwestycyjnym, między co najmniej dwoma państwami członkowskimi lub pomiędzy państwami członkowskimi i państwami trzecimi" ${ }^{26}$. Swoboda przepływu kapitału oznacza, że inwestorzy podejmujący decyzję o miejscu ulokowania kapitału mogą kierować się przede wszystkim kryterium gospodarczej atrakcyjności i nie muszą obawiać się prawnych czy administracyjnych przeszkód ${ }^{27}$.

Co istotne, zgodnie $\mathrm{z}$ utrwalonym orzecznictwem przepływ kapitału obejmuje zwłaszcza te czynności, poprzez które nierezydenci dokonują inwestycji w nieruchomości na terytorium państwa członkowskiego ${ }^{28}$. Do kategorii inwestycji w nieruchomości należy nie tylko nabycie prawa własności, ale także nabycie prawa użytkowania nieruchomości zabudowanych i niezabudowanych ${ }^{29}$.

W literaturze zamiennie z pojęciem „swoboda przepływu kapitału” używane jest także pojęcie ,zasada swobody przepływu kapitału” ${ }^{\text {"30. Takie }}$ ujmowanie swobody przepływu kapitału uzasadniane jest tym, że swobody traktatowe są fundamentem europejskiego rynku wewnętrznego, a swoboda przepływu kapitału jest niezbędna do tego, aby pozostałe swobody mogły funkcjonować prawidłowo, i dlatego zarówno w literaturze, jak i w orzecznictwie uznaje się ją za doniosłą ${ }^{31}$. Poza tym treściowa nadrzędność tej swobody w stosunku do innych wyraża się w tym, że jako norma kierowana do państw członkowskich zakazuje wszelkich działań, które ograniczałyby swobodny przepływ kapitału, a zatem oddziałuje na cały system prawny państw członkowskich ${ }^{32}$.

${ }^{26}$ A. Zawidzka-Łojek, Swoboda przepływu kapitatu, w: A. Zawidzka-Łojek, A. Łazowski (red.), Podręcznik prawa Unii Europejskiej. Instytucje i porzadek prawny. Prawo materialne, Warszawa 2018, s. 444.

${ }^{27}$ M. Mataczyński, w: A. Wróbel (red.), Traktat..., s. 977.

${ }^{28}$ Wyroki TSUE: z 21 maja 2019 r. w sprawie C-235/17, Komisja v. Węgry, ECLI: EU:C:2019:432, pkt 54; z 6 marca 2018 r. w sprawach C-52/16 i C-113/16, SEGRO i Horváth, ECLI:EU:C:2018:157, pkt 56; z 28 października 2010 r. w sprawie C-72/09, Rimbaud, ECLI: EU:C:2010:645, pkt 17. Podobnie wyroki: z 16 marca 1999 r. w sprawie C-222/97, Trummer i Mayer, ECLI:EU:C:1999:143, pkt 21; z 11 stycznia 2001 r. w sprawie C-464/98, Stefan, ECLI: EU:C:2001:9, pkt 5; z 5 marca 2002 r. w sprawach połączonych C-515/99, od C-519/99 do C-524/99 i od C-526/99 do C-540/99, Reisch i in., ECLI:EU:C:2002:135, pkt 30; z 14 września 2006 r. w sprawie C-386/04, Centro di Musicologia Walter Stauffer, ECLI:EU:C:2006:568, pkt 22; w sprawie C-302/97, Korde v Austria ECR 1-3099; w sprawie C-4283/98, Albore, ECLI: EU:C:2000:401, pkt 14.

${ }^{29}$ Wyroki TSUE: z 21 maja 2019 r. w sprawie C-235/17, Komisja v. Węgry, ECLI: EU:C:2019:432, pkt 55; z 6 marca 2018 r. w sprawach C-52/16 i C-113/16, SEGRO i Horváth, ECLI: EU:C:2018:157, pkt 57.

${ }^{30}$ M. Mataczyński, w: A. Wróbel (red.), Traktat..., s. 982.

${ }^{31}$ Ibidem.

32 Ibidem. 
Warto zauważyć, że w art. 63 TFUE mowa jest o przepływie kapitału i przepływie płatności, co wskazuje na to, iż przepływ kapitału nie jest tożsamy z przepływem płatności. Swoboda przepływu płatności, w przeciwieństwie do swobodnego przepływu kapitału, nie ma charakteru samoistnego, ale służy korzystaniu $\mathrm{z}$ innych swobód ${ }^{33}$. Swoboda przepływu płatności odnosi się do bieżących płatności będących transferem obcej waluty w wykonaniu zobowiązań wzajemnych na podstawie umów, natomiast swoboda przepływu kapitału jest operacją finansową mającą na celu lokatę lub inwestycję kapitałową, a nie wynagrodzenie za usługę ${ }^{34}$. W kwestii ograniczeń w obrocie nieruchomościami znaczenie ma swoboda przepływu kapitału.

W przypadku swobody przepływu kapitału dopiero w Traktacie z Maastricht wprowadzono przepisy zakazujące wszelkich ograniczeń w przepływie kapitału, zaś w wersji pierwotnej przepisy regulujące tę swobodę przewidywały jedynie liberalizację $\mathrm{w}$ zakresie niezbędnym do sprawnego funkcjonowania wspólnego rynku. W orzecznictwie TSUE art. 63 TFUE został uznany za bezpośrednio skuteczny, wprowadza bowiem jasny i bezwarunkowy zakaz niewymagający dla swej skuteczności żadnych środków implementujących ${ }^{35}$. Przyznaje on zatem jednostkom prawa, na które mogą się powoływać przed sądami krajowymi i do których ochrony sądy krajowe są zobowiązane ${ }^{36}$. Chodzi tu jednak o wertykalny skutek bezpośredni (tj. w relacji jednostka - państwo). Nie została natomiast w orzecznictwie TSUE rozstrzygnięta kwestia jego horyzontalnego skutku bezpośredniego, to znaczy czy jest on poza państwami członkowskimi skierowany także do podmiotów prywatnych (w szczególności banków i instytucji finansowych) ${ }^{37}$. W kontekście ograniczeń obrotu nieruchomościami to jednak wertykalny skutek bezpośredni art. 63 TFUE ma znaczenie, ponieważ zarówno dyrektor generalny KOWR przy rozpatrywaniu wniosku o zgodę na nabycie nieruchomości rolnej, jak i sąd w przypadku wniesienia skargi na odmowę wyrażenia zgody przez dyrektora generalnego KOWR na nabycie nieruchomości rolnej powinny uwzględnić przepisy traktatowe kształtujące zasadę swobodnego przepływu kapitału i wyjątki od niej.

${ }^{33}$ Ibidem, s. 993.

${ }^{34}$ Wyrok TSUE z 31 stycznia 1984 r. w sprawach połączonych 286/82 i 26/83, Luisi i Carbone, ECLI:EU:C:1984:35, pkt 21.

${ }^{35}$ Wyrok TSUE z 14 grudnia 1995 r. w sprawach połączonych C-163/94, C-165/94 oraz C-250/94, Sanz de Lera i in., ECLI:EU:C:1995:451, pkt 41. Zob. też: M. Mataczyński, w: A. Wróbel (red.), Traktat..., s. 979; A. Zawidzka-Łojek, Swoboda przepływu kapitału..., s. 441.

${ }^{36}$ Wyrok TSUE z 14 grudnia 1995 r. w sprawach połączonych C-163/94, C-165/94 oraz C-250/94, Sanz de Lera i in., ECLI:EU:C:1995:451, pkt 43.

${ }^{37}$ A. Frąckowiak-Adamska, Zasada proporcjonalności jako gwarancja swobód rynku wewnętrznego Wspólnoty Europejskiej, Warszawa 2009, s. 119; A. Zawidzka-Łojek, Swoboda przepływu kapitału..., s. 442. 
Jak wynika z utrwalonego orzecznictwa, do środków zakazanych przez art. 63 ust. 1 TFUE, stanowiących ograniczenia w przepływie kapitału, zalicza się głównie te, które mogą zniechęcić osoby niebędące rezydentami do dokonania inwestycji w danym państwie członkowskim ${ }^{38}$. Trybunał przyjmuje zatem niezwykle szeroką koncepcję ograniczenia swobody przepływu kapitału, gdyż obejmuje ona wszelkie przepisy prawa krajowego, które nawet potencjalnie „mogą” zniechęcać do dokonania inwestycji, a zwłaszcza do nabywania nieruchomości. TSUE uznał za przepisy ograniczające swobodę przepływu kapitału m.in. przepisy prawa krajowego wymagające uzyskania uprzedniego zezwolenia na nabycie nieruchomości (jak w sprawach Konle i Salzmann ${ }^{39}$ ).

Nie budzi wątpliwości, że wprowadzone w 2016 r. ograniczenia w obrocie nieruchomościami, w tym zasada, iż nabywcą nieruchomości rolnych może być wyłącznie rolnik indywidualny, z wyłączeniem wyjątków ustawowych, stanowi ograniczenie swobodnego przepływu kapitału w rozumieniu art. 63 TFUE. Ograniczeniem takim są także istniejące jeszcze przed nowelizacją z 2016 r. prawo pierwokupu i prawo nabycia przysługujące KOWR.

\section{Podstawy wprowadzenia regulacji krajowych ograniczających zasadę przepływu kapitału}

Swoboda przepływu kapitału, podobnie jak pozostałe swobody traktatowe (swoboda przepływu towarów, usług, osób), nie ma charakteru absolutnego, a w TFUE dopuszcza się klauzule derogacyjne ${ }^{40}$. Na mocy art. 65 TFUE państwa członkowskie uprawnione są do podejmowania wszelkich środków niezbędnych do zapobiegania naruszeniom ich ustaw i aktów wykonawczych, zwłaszcza w sferze podatkowej i w dziedzinie nadzoru ostrożnościowego nad instytucjami finansowymi, lub ustanowienia procedur deklarowania przepływu kapitału do celów informacji administracyjnej bądź statystycznej lub podejmowania środków uzasadnionych powodami związanymi z porządkiem publicznym lub bezpieczeństwem publicznym, przy czym środki

${ }^{38}$ Wyroki TSUE: z 6 marca 2018 r. w sprawach C-52/16 i C-113/16, SEGRO i Horváth, ECLI: EU:C:2018:157, pkt 65; z 25 stycznia 2007 r. w sprawie C-370/05, Festersen, EU:C:2007:59, pkt 24; z 23 lutego 2006 r. w sprawie C-513/03, Van Hilten-van der Heijden, ECLI:EU:C:2006:131, pkt 44; z 1 października 2009 r. w sprawie C-567/07, Woningstichting Sint Servatius, EU:C:2009:593, pkt 21.

${ }^{39}$ Wyrok TSUE z 1 czerwca 1999 r. w sprawie C-302/97, Klaus Konle, ECLI:EU:C:1999:271, pkt 39; z 15 maja 2003 r. w sprawie C-300/01, Salzmann, ECLI: EU:C:2003:283, pkt 41.

${ }^{40}$ A. Frąckowiak-Adamska, Zasada proporcjonalności..., s. 121 i 137; B. Jeżyńska, R. Pastuszko, Ramy prawne..., s. 13. 
te nie powinny stanowić arbitralnej dyskryminacji ani ukrytego ograniczenia w swobodnym przepływie kapitału (art. 65 ust 1 pkt b TFUE).

Wyjątki traktatowe sformułowane w art. 65 TFUE interpretowane są zawężająco ${ }^{41}$. Ratio legis art. 65 TFUE wyklucza stosowanie przez państwo członkowskie środków o charakterze protekcjonistycznym, a wyjątki traktatowe mogą być stosowane w celu usprawiedliwiania przepisów krajowych zarówno dyskryminacyjnych (pod warunkiem że nie jest to arbitralna dyskryminacja), jak i stosowanych bez zróżnicowania ${ }^{42}$.

W orzecznictwie TSUE przyjęto jednak dość szeroką interpretację pojęcia interesu publicznego, uznając, że obejmuje on zarówno bezpieczeństwo wewnętrzne, jak i zewnętrzne ${ }^{43}$. W konsekwencji TSUE w odniesieniu do swobody przepływu towarów uznał m.in. dopuszczalność ze względu na bezpieczeństwo publiczne wprowadzenia ograniczeń w obrocie „materiałami strategicznymi" "44, a w przypadku swobody przepływu kapitału względy bezpieczeństwa publicznego pozwoliły na uznanie dopuszczalności regulacji dyskryminującej obywateli innych państw członkowskich w nabywaniu nieruchomości w obszarach wyznaczonych jako tereny o znaczeniu militarnym, o ile jednak wykazane zostanie, że niedyskryminacyjne traktowanie obywateli państw członkowskich naraziłoby interesy wojskowe danego państwa członkowskiego na rzeczywiste, specyficzne i poważne zagrożenia, którym nie można przeciwdziałać za pomocą mniej restrykcyjnych procedur (wyrok w sprawie C-423/98 Albore $^{45}$ ).

Jak wynika z orzecznictwa TSUE, przepisy krajowe ograniczające swobodę przepływu kapitału mogą być uzasadnione względami wymienionymi w art. 65 TFUE (wyjątki traktatowe), ale mogą być też dopuszczone wtedy, gdy będzie to uzasadnione "nadrzędnymi względami interesu ogólnego" (wyjątki orzecznicze) $)^{46}$. Wyjątki orzecznicze, w przeciwieństwie do wyjątków traktatowych, dotyczą wyłącznie przepisów niedyskryminacyjnych ${ }^{47}$. Podobnie zatem jak w przypadku pozostałych swobód, poza wartościami wymienionymi wprost w Traktacie TSUE uznał za godne ochrony także

${ }^{41}$ A. Zawidzka-Łojek, Swoboda przepływu kapitału..., s. 457.

${ }^{42}$ Ibidem.

${ }^{43}$ Wyrok TSUE z 4 października 1991 r. w sprawie C-367/89, Richardt and „Les Accessoires Scientifiques", ECLI:EU:C:1991:376, pkt 22.

${ }^{44}$ Ibidem.

${ }^{45}$ Wyrok TSUE z 13 lipca 2000 r. w sprawie C-423/98, Alfredo Albore, ECLI:EU:C:2000:401, pkt 18 i 24.

${ }^{46}$ Wyrok TSUE z 6 marca 2018 r. w sprawach C-52/16 i C-113/16, SEGRO i Horváth, ECLI: EU:C:2018:157, pkt 77-80 i przytoczone tam orzecznictwo. Zob. też: A. Zawidzka-Łojek, Swoboda przeptywu kapitału..., s. 460.

${ }^{47}$ A. Zawidzka-Łojek, Swoboda przepływu kapitału..., s. 457. 
inne wartości określane jako „wymogi konieczne”, „wymogi imperatywne" lub w przypadku swobody przepływu kapitału - „nadrzędne względy interesu ogólnego" (ang. imperative requirements in the general interest) ${ }^{48}$. Dopuszczenie niewymienionych w Traktacie wartości dla usprawiedliwienia instrumentów ograniczających poszczególne swobody przez państwa członkowskie pierwszy raz miało miejsce na gruncie swobody przepływu towarów ${ }^{49}$ (w wyroku w sprawie C-120/78 Cassis de Dijon ${ }^{50}$ ). W odniesieniu do swobody przepływu kapitału doktryna wymogów koniecznych znalazła zastosowanie dopiero na początku lat 90. Pierwszym wyrokiem, w którym można odnaleźć zaczątki tej doktryny w odniesieniu do swobody przepływu kapitału, jest wyrok w sprawie Veronica Omroep ${ }^{51}$, w którym TSUE, odpowiadając na pytanie prejudycjalne, uznał, że uzasadnieniem ograniczeń swobody przepływu kapitału może być konieczność zapewnienia „pluralistycznego i niekomercyjnego charakteru systemu audiowizualnego wprowadzonego przez dane państwo", co wykraczało poza dopuszczony traktatem zakres ograniczenia tej swobody ${ }^{52}$. W wyroku w sprawie C-55/94 Gebhard ${ }^{53}$ TSUE z kolei używał już ogólnego sformułowania, mówiąc o „krajowych środkach mogących utrudniać lub zniechęcać do korzystania z podstawowych swobód”, uznając w ten sposób możliwość stosowania „doktryny wymogów koniecznych" do wszystkich czterech swobód prawa Unii Europejskiej ${ }^{54}$. Potwierdzenie zastosowania pojęcia wymogów imperatywnych do swobody przepływu kapitału można znaleźć w orzeczeniu Komisja przeciwko Portugalii $^{55}$. W orzeczeniu tym TSUE wskazał, że ,swoboda przepływu kapitału jako jedna $\mathrm{z}$ fundamentalnych zasad traktatowych może być ograniczona

${ }^{48}$ A. Frąckowiak-Adamska, Zasada proporcjonalności..., s. 128 i 138; B. Jeżyńska, R. Pastuszko, Ramy prawne..., s. 14.

49 A. Frąckowiak-Adamska, Zasada proporcjonalności..., s. 128 i 133.

${ }^{50}$ Wyrok TSUE z 20 lutego 1979 r. w sprawie C-120/78, Rewe-Zentral AG przeciwko Bundesmonopolverwaltung fur Branntwein, ECLI:EU:C:1979:42 (tzw. Cassis de Dijon). Spowodowane było to $\mathrm{w}$ głównej mierze bardzo szeroką definicją środków równoważnych do ograniczeń ilościowych, sformułowaną w wyroku TSUE w sprawie C-8/74 Dassonville (wyrok TSUE z 11 lipca 1974 r. w sprawie C-8/74, Procureur du Roi przeciwko Benoît i Gustave Dassonville, ECLI:EU:C:1974:82), na podstawie której każde, nawet najmniejsze ograniczenie swobodnego przepływu towarów niemające podstawy prawnej w traktatach mogło zostać uznane za sprzeczne z prawem unijnym.

${ }^{51}$ Wyrok TSUE z 3 lutego 1993 r. w sprawie C-148/91, Veronica Omroep, ECLI:EU:C:1993:45.

52 A. Frąckowiak-Adamska, Zasada proporcjonalności..., s. 138.

53 Wyrok TSUE z 30 listopada 1995 r. w sprawie C-55/94, Reinhard Gebhard przeciwko Consiglio dell'Ordine degli Avvocati e Procuratori di Milano, ECLI:EU:C:1995:411.

${ }^{54}$ Ibidem, pkt 37.

${ }_{55}$ Wyrok TSUE z 4 czerwca 2002 r. w sprawie C-367/98, Komisja przeciwko Portugalii, ECLI:EU:C:2002:326. 
jedynie poprzez przepisy krajowe usprawiedliwione na podstawie art. 73d Traktatu (obecnie art. 65 ust. 1 TFUE) lub przez odwołanie się do wymogów imperatywnych interesu publicznego. W tym drugim przypadku przepisy muszą być stosowane do wszystkich osób i przedsiębiorstw prowadzących działalność na terytorium państwa przyjmującego" ${ }^{56}$. Ponadto dla usprawiedliwienia na podstawie wymogów imperatywnych przepisy krajowe powinny być właściwe dla osiągnięcia celu, jakiemu służą, oraz nie mogą przekraczać tego, co jest konieczne, dla osiągnięcia tego celu, tak aby były zgodne z zasadą proporcjonalności ${ }^{57}$.

Katalog wymogów imperatywnych interesu publicznego stanowi otwartą listę. W wielu orzeczeniach TSUE odwoływał się do różnego rodzaju wartości, które uznawał za przesłanki uzasadniające ograniczenie swobody przepływu kapitału ${ }^{58}$. Dla usprawiedliwienia wprowadzenia w prawie krajowym przepisów skutkujących ograniczeniem w obrocie nieruchomościami TSUE dopuścił możliwość powołania się na cele gospodarki przestrzennej w interesie ogólnym, takie jak: zachowanie w niektórych regionach stałej populacji i działalności gospodarczej niezależnej od sektora turystycznego ${ }^{59}$. W kontekście przepisów krajowych dotyczących bezpośrednio nieruchomości rolnych Trybunał uznał, iż uregulowania krajowe mogą ograniczać swobodny przepływ kapitału ze względu na cele, takie jak: (1) zachowanie tradycyjnej formy eksploatacji gruntów rolnych poprzez zagospodarowanie bezpośrednie; (2) zapewnienie, aby nieruchomości rolne były w większości zamieszkane i uprawiane przez ich właścicieli; (3) utrzymanie do celów zagospodarowania przestrzennego stałej populacji na obszarach wiejskich; (4) wspieranie rozsądnego użytkowania dostępnych gruntów, zwalczając nacisk rynku nieruchomości; (5) zachowanie rozdziału własności ziemskiej w sposób pozwalający na rozwój rentownych gospodarstw rolnych i harmonijne zarządzanie przestrzenią oraz krajobrazem ${ }^{60}$. TSUE zwrócił

${ }^{56}$ Ibidem, pkt 49.

${ }^{57}$ Ibidem.

${ }^{58}$ Szczegółowe omówienie orzeczeń: B. Jeżyńska, R. Pastuszko, Ramy prawne..., s. 15-20; M. Giżewski, Restrictions on Trading in Agricultural Land and European Union Law, „Studia Iuridica" 2017, t. 71, s. 54-55; J. Pietrzak, Ograniczenia w obrocie nieruchomościami rolnymi wświetle wybranego orzecznictwa Trybunału Sprawiedliwości Unii Europejskiej, „Młody Jurysta” 2018, nr 2, s. 61-71.

${ }^{59}$ Wyrok TSUE z 1 czerwca 1999 r. w sprawie C-302/97, Klaus Konle przeciwko Republik Österreich, ECLI:EU:C:1999:271, pkt 40.

${ }^{60}$ Cele wskazane w pkt 1-4 zostały wymienione w wyroku TSUE z 25 stycznia 2007 r. w sprawie C-370/05, Festersen, ECLI:EU:C:2007:59, pkt 27-28, natomiast cel wskazany w pkt 5 został wymieniony w wyroku TSUE z 23 września 2003 r. w sprawie C-452/01, Ospelt i Schlössle Weissenberg, EU:C:2003:493, pkt 39. Wszystkie te cele zostały potwierdzone przez TSUE w wyrokach: 
też uwagę, że cele te są zgodne ze Wspólną Polityką Rolną, która na mocy art. 39 ust. 1 lit. b) TFUE ma na celu ,zapewnienie [...] odpowiedniego poziomu życia ludności wiejskiej” i której ustalanie powinno uwzględniać, zgodnie z ust. 2 lit. a) tego artykułu, „szczególny charakter gospodarki rolnej, wynikający ze struktury społecznej rolnictwa oraz z różnic strukturalnych i przyrodniczych między poszczególnymi regionami rolniczymi" ${ }^{61}$.

Samo powołanie się na uzasadnione nadrzędne względy interesu ogólnego nie jest jednak wystarczające do wprowadzenia przepisów krajowych, które mogą skutkować ograniczeniem swobody przepływu kapitału. $\mathrm{Z}$ orzecznictwa Trybunału wynika, że przepisy krajowe mogące utrudniać lub zniechęcać do korzystania z podstawowych swobód chronionych na mocy traktatu muszą spełniać cztery warunki: (1) być stosowane w sposób niedyskryminacyjny, (2) być uzasadnione nadrzędnymi względami interesu ogólnego, (3) prowadzić do realizacji celu, jakiemu służą (wymóg adekwatności), (4) nie wykraczać poza zakres konieczny do jego osiągnięcia (wymóg proporcjonalności $)^{62}$.

Ograniczenia w obrocie nieruchomościami rolnymi uregulowane w ustawie o kształtowaniu ustroju rolnego, w tym te wprowadzone ustawą o wstrzymaniu sprzedaży nieruchomości Zasobu Własności Rolnej Skarbu Państwa oraz o zmianie niektórych ustaw, należy zatem ocenić w kontekście przywołanego wyżej testu.

\section{Prawo pierwokupu i prawo nabycia w świetle zasady swobodnego przepływu kapitału}

Pierwotnie w ustawie o kształtowaniu ustroju rolnego przewidziane były jedynie dwa instrumenty, które miały przyczyniać się do realizacji celów tej

\footnotetext{
z 21 maja 2019 r. w sprawie C-235/17, Komisja v. Węgry, ECLI:EU:C:2018:157, pkt 91-92; z 6 marca 2018 r., w sprawach C-52/16 i C-113/16, SEGRO i Horváth, ECLI:EU:C:2018:157, pkt 82; z 25 stycznia 2007 r. w sprawie C-370/05, Festersen, EU:C:2007:59. Zob. też: A. Zawidzka-Łojek, Swoboda przeptywu kapitatu..., s. 461.

${ }^{61}$ Wyroki TSUE w sprawie C-370/05, Festersen, ECLI:EU:C:2007:59, pkt 28; z 23 września 2003 r. w sprawie C-452/01, Ospelt i Schlössle Weissenberg, ECLI: EU:C:2003:493, pkt 40.

${ }^{62}$ B. Jeżyńska, R. Pastuszko, Ramy prawne..., s. 15. Zob. też: wyroki TSUE: z 30 listopada 1995 r. w sprawie C-55/94, Gebhard, ECLI:EU:C:1995:411, pkt 37; z 25 stycznia 2007 r. w sprawie C-370/05, Festersen, EU:C:2007:59, pkt 26; z 31 marca 1993 r. w sprawie C-19/92, Kraus, ECLI:EU:C:1993:125, pkt 32; z 1 czerwca 1999 r. w sprawie C-302/97, Klaus Konle, ECLI:EU:C:1999:271, pkt 40; z 23 września 2003 r. w sprawie C-452/01, Ospelt i Schlössle Weissenberg, ECLI:EU:C:2003:493, pkt 34; z 6 marca 2018 r. w sprawie C-52/16 i C-113/16, SEGRO i Horváth, ECLI:EU:C:2018:157, pkt 76.
} 
ustawy (celu ogólnego w postaci kształtowania ustroju rolnego oraz celów szczegółowych, w tym poprawy struktury obszarowej gospodarstw rolnych, przeciwdziałania nadmiernej koncentracji nieruchomości rolnych oraz zapewnienia prowadzenia działalności rolniczej w gospodarstwach rolnych przez osoby o odpowiednich kwalifikacjach). Instrumenty te to prawo pierwokupu przysługujące Agencji Nieruchomości Rolnych (obecnie Krajowemu Ośrodkowi Wsparcia Rolnictwa) działającej na rzecz Skarbu Państwa oraz analogiczne do prawa pierwokupu prawo nabycia, przysługujące KOWR w przypadku przenoszenia własności nieruchomości rolnej na podstawie innej umowy niż umowa sprzedaży, a po nowelizacji z 2016 r. przysługujące KOWR w każdym przypadku nabywania nieruchomości rolnej, z wyłączeniem nabywania na podstawie umowy sprzedaży.

Przyznanie KOWR prawa pierwokupu, a także prawa nabycia może zniechęcać obywateli innych państw członkowskich do nabywania nieruchomości rolnych w Polsce, trzeba je zatem uznać za instrument ograniczający swobodny przepływ kapitału w rozumieniu art. 63 TFUE.

Dokonując oceny tych instrumentów poprzez wypracowany w orzecznictwie TSUE test, można wskazać, że nie ma podstaw do uznania, iż rozwiązanie to jest dyskryminacyjne wobec obywateli innych państw członkowskich. Skorzystanie z prawa pierwokupu lub nabycia w takim samym stopniu dotyczy bowiem obywateli Polski, jak i obywateli pozostałych państw członkowskich. Co do nadrzędnych względów interesu ogólnego usprawiedliwiających ograniczenie swobody przepływu kapitału TSUE uznał, że uregulowania krajowe mogą ograniczać swobodny przepływ kapitału ze względu na cele, takie jak zachowanie eksploatacji gruntów rolnych poprzez zagospodarowanie bezpośrednie oraz zamieszkiwanie i uprawianie nieruchomości rolnych w większości przez ich właścicieli63. Dopuścił też takie cele, jak zachowanie rozdziału własności ziemskiej w sposób pozwalający na prawidłowy rozwój upraw ${ }^{64}$. Wprowadzenie prawa pierwokupu i prawa nabycia znajduje uzasadnienie $\mathrm{w}$ tych celach, skutkuje bowiem nabyciem nieruchomości rolnych do Zasobu Własności Rolnych Skarbu Państwa, a jak wynika $\mathrm{z}$ art. 24 ust. 1 ustawy o gospodarowaniu nieruchomościami rolnymi Skarbu Państwa, KOWR gospodaruje tym zasobem w pierwszej kolejności w drodze dzierżawy albo sprzedaży nieruchomości rolnych na powiększenie

${ }^{63}$ Wyroki TSUE: z 25 stycznia 2007 r. w sprawie C-370/05, Festersen, ECLI:EU:C:2007:59, pkt 27-28; z 6 marca 2018 r. w sprawach C-52/16 i C-113/16, SEGRO i Horváth, ECLI: EU:C:2018:157, pkt 82.

${ }^{64}$ Wyroki TSUE: z 23 września 2003 r. w sprawie C-452/01, Ospelt i Schlössle Weissenberg, ECLI: EU:C:2003:493, pkt 39; z 6 marca 2018 r. w sprawach C-52/16 i C-113/16, SEGRO i Horváth, ECLI:EU:C:2018:157, pkt 83. 
lub utworzenie gospodarstw rodzinnych. Takie rozwiązanie można więc uznać za prowadzące do realizacji tych celów oraz niewykraczające poza zakres konieczny do ich osiągnięcia, zwłaszcza biorąc pod uwagę zakres wyłączeń oraz to, że prawo pierwokupu i prawo nabycia nie przysługuje, gdy nieruchomość rolna jest nabywana w celu powiększenia gospodarstwa rodzinnego do powierzchni nieprzekraczającej 300 ha, a jest ona położona w gminie, w której ma miejsce zamieszkania nabywca, lub w gminie graniczącej z tą gminą (art. 3 ust. 7 oraz art. 4 ust. 4 pkt 1 u.k.u.r.).

Instrumenty $\mathrm{w}$ postaci prawa pierwokupu i prawa nabycia okazały się jednak niewystarczające do realizacji celów ustawy o kształtowaniu ustroju rolnego wobec tendencji na rynku nieruchomości rolnych w Unii Europejskiej. Jak zwraca się uwagę w literaturze, z perspektywy kilkunastu lat obowiązywania ustawy o kształtowaniu ustroju rolnego widać, że rozwiązania przyjęte w jej pierwotnym brzmieniu, mimo że były kilkakrotnie korygowane, nie odegrały istotnej roli w stymulowaniu przemian struktury obszarowej gospodarstw rolnych ${ }^{65}$. Ustawą o wstrzymaniu sprzedaży nieruchomości Zasobu Własności Rolnej Skarbu Państwa oraz o zmianie niektórych ustaw z dniem 30 kwietnia 2016 r. wprowadzono zatem kolejne instrumenty mające służyć realizacji celów ustawy o kształtowaniu ustroju rolnego, które w sposób istotny ograniczają obrót nieruchomościami rolnymi w Polsce.

\section{Zasada nabywania nieruchomości rolnych przez rolników indywidualnych w świetle zasady swobodnego przepływu kapitału}

Z dniem 30 kwietnia 2016 r. przyjęta została zasada, zgodnie z którą nabywcą nieruchomości rolnej może być wyłącznie rolnik indywidualny, tj. osoba fizyczna, posiadająca określone w ustawie o kształtowaniu ustroju rolnego kwalifikacje rolnicze, osobiście prowadząca od co najmniej 5 lat gospodarstwo rodzinne i $\mathrm{w}$ tym okresie zamieszkująca na terenie gminy w której położona jest co najmniej jedna nieruchomość wchodząca w skład gospodarstwa, będąca właścicielem, użytkownikiem wieczystym, posiadaczem samoistnym lub dzierżawcą nieruchomości rolnych, których łączna powierzchnia użytków rolnych nie przekracza 300 ha. Jednocześnie przyjęto zasadę, że powierzchnia nabywanej nieruchomości rolnej wraz

${ }^{65}$ K. Marciniuk, Prawne instrumenty ingerencji władzy publicznej w obrót nieruchomościami rolnymi jako środki kształtowania ustroju rolnego, Białystok 2019, s. 341; idem, w: P. Czechowski (red.), Prawo rolne, Warszawa 2017, s. 220-221. 
z powierzchnią nieruchomości rolnych wchodzących wcześniej w skład gospodarstwa rodzinnego nabywcy nie może przekraczać 300 ha użytków rolnych. Od obu tych zasad przewidziano szereg wyjątków, przy czym ich zakres uległ rozszerzeniu w związku z ustawą z 26 kwietnia 2019 r. o zmianie ustawy o kształtowaniu ustroju rolnego oraz niektórych innych ustaw, która weszła w życie 25 czerwca 2019 r.

Należy podkreślić, że TSUE uznał zachowanie tradycyjnej formy uprawy gruntów rolnych poprzez zagospodarowanie bezpośrednie oraz zapewnienie, by nieruchomości rolne w większości zamieszkiwali i uprawiali ich właściciele, za dopuszczalny wymóg interesu publicznego, który może stanowić podstawę wprowadzenia ograniczeń $\mathrm{w}$ obrocie nieruchomościami ${ }^{66}$. Jednocześnie TSUE zastrzegł, że niedozwolone jest bezwzględne stosowanie tego wymogu $^{67}$. Istotna jest więc nie tyle sama zasada, ile zakres przewidzianych od niej wyjątków w ustawie o kształtowaniu ustroju rolnego.

Spośród kryteriów, jakie muszą być spełnione, aby można było uznać daną osobę za rolnika indywidualnego, przy uwzględnieniu zakresu wyjątków, wątpliwości w kontekście zasady swobodnego przepływu kapitału budzi wymóg zamieszkiwania w gminie, na obszarze której położona jest jedna z nieruchomości rolnych wchodzących w skład gospodarstwa rolnego, a także ograniczenie nabywania do osób fizycznych (art. 6 ust. 1 u.k.u.r.).

\subsection{Ograniczenie nabywania nieruchomości rolnych przez osoby prawne}

Rolnikiem indywidualnym może być wyłącznie osoba fizyczna, co stanowi odwołanie do art. 23 Konstytucji, zgodnie z którym podstawą ustroju rolnego jest gospodarstwo rodzinne. Tylko osoby fizyczne mogą tworzyć rodzinę ${ }^{68}$, a zatem tylko osoby fizyczne mogą prowadzić gospodarstwo ro-

${ }^{66}$ Wyroki TSUE: z 25 stycznia 2007 r. w sprawie C-370/05, Festersen, ECLI:EU:C:2007:59, pkt 27 i 28; z 23 września 2003 r. w sprawie C-452/01, Ospelt i Schlössle Weissenberg, ECLI: EU:C:2003:493, pkt 40.

${ }^{67}$ Wyrok TSUE z 23 września 2003 r. w sprawie C-452/01, Ospelt i Schlössle Weissenberg, ECLI:EU:C:2003:493, pkt 54.

${ }^{68}$ Pojęcie „rodzina” zarówno w języku potocznym, jak i w przepisach prawa wiązane jest z osobami fizycznymi. W Stowniku języka polskiego rodzina definiowana jest jako „małżonkowie i ich dzieci; ogólniej też: osoby związane pokrewieństwem i powinowactwem” Zob. Stownik języka polskiego PWN, https://sjp.pwn.pl/sjp/rodzina;2515555.html [dostęp: 13.07.2018]. Jednoznaczne odniesienia do osób fizycznych w związku z użyciem słowa „rodzina” znajdują się też w prawie, zob. np. art. 18, 33 ust. 1, 47, 71 Konstytucji, art. $446 \S 3,680^{1}, 686,832,1008$ k.c. czy Kodeks rodzinny i opiekuńczy. 
dzinne. W konsekwencji zasada nabywania nieruchomości przez rolników indywidualnych prowadzi do ograniczenia możliwości nabywania nieruchomości rolnych przez osoby prawne, a w orzecznictwie TSUE ograniczenia nabywania nieruchomości rolnych przez osoby prawne uznawane są za naruszenie zasady swobodnego przepływu kapitału ${ }^{69}$. Zasadne jest więc dokonanie oceny, czy przyjęte w tym zakresie rozwiązanie przechodzi test wypracowany w orzecznictwie TSUE.

Zgodnie z przyjętym w ustawie o kształtowaniu ustroju rolnego rozwiązaniem osoba prawna może nabyć nieruchomość rolną wyłącznie w przypadku zaistnienia określonych wyjątków ustawowych (np. w ramach postępowań egzekucyjnych, upadłościowych, restrukturyzacyjnych oraz w związku z podziałem, przekształceniem i łączeniem spółek) lub na podstawie zgody dyrektora generalnego KOWR, o której mowa w art. 2a ust. 4 pkt 1 u.k.u.r. $\mathrm{Z}$ pewnością niezgodne z zasadą swobody przepływu kapitału oraz z zasadą swobody przedsiębiorczości byłoby rozwiązanie skutkujące niemożnością nabywania nieruchomości rolnych przez osoby prawne. Przyjęte przez polskiego prawodawcę rozwiązania pozwalają jednak nabywać nieruchomości rolne osobom prawnym na zasadzie wyjątków. Powstaje jednak pytanie, czy przyjęty zakres wyjątków od generalnej zasady jest wystarczający.

Przede wszystkim istotnie ograniczona jest możliwość nabycia przez osobę prawną (ale także przez osobę fizyczną niebędącą rolnikiem indywidualnym lub osobą bliską) nieruchomości rolnej na podstawie umowy sprzedaży. Nabycie takie może odbyć się poza wyjątkami ustawowymi wyłącznie za zgodą dyrektora generalnego KOWR wydaną na wniosek zbywcy i przy wykazaniu, że nie było możliwości sprzedaży nieruchomości rolnej rolnikowi indywidualnemu, co w przypadku atrakcyjnych nieruchomości rolnych będzie trudne do spełnienia. Wymóg ten nie musi być jednak spełniony w sytuacji, gdy nabycie nieruchomości rolnej za zgodą dyrektora generalnego KOWR na wniosek zbywcy następuje na innej podstawie niż umowa sprzedaży. Rozwiązanie takie powoduje jednak utrudnienie w nabywaniu nieruchomości rolnych przez osoby prawne, które już prowadzą działalność rolniczą, a które są zainteresowane powiększeniem areału nieruchomości rolnych wchodzących w zakres ich gospodarstwa rolnego, $i$ to nieruchomości o określonych parametrach, właściwych dla rodzaju prowadzonej przez nie działalności rolniczej. Rozwiązanie to może więc budzić wątpliwości, zwłaszcza z uwagi na zasadnie przyjęty warunek związany z nabyciem nieruchomości rolnej za zgodą dyrektora generalnego KOWR,

${ }^{69}$ Wyrok TSUE: z 23 września 2003 r. w sprawie C-452/01, Ospelt i Schlössle Weissenberg, ECLI: EU:C:2003:493, pkt 51. 
zgodnie z którym nabywca może nabyć nieruchomość rolną, jeśli zobowiąże się do prowadzenia na niej działalności rolniczej, a w wyniku nabycia nieruchomości rolnej nie dojdzie do nadmiernej koncentracji gruntów rolnych. Wątpliwości dotyczą także tego, że w przypadku osób prawnych z wnioskiem o zgodę musi wystąpić zbywca, a nie podmiot zainteresowany nabyciem (co stanowi dodatkowe utrudnienie dla nabywcy). Z drugiej strony, istniejące rozwiązania nie pozbawiają takich podmiotów możliwości powiększania gospodarstwa rolnego, nabycie może bowiem nastąpić na innej podstawie niż umowa sprzedaży za zgodą dyrektora generalnego KOWR, ale bez konieczności wykazywania braku możliwości zbycia nieruchomości rolnej rolnikowi indywidualnemu. Ponadto bez ograniczeń można nabyć nieruchomości rolne o powierzchni mniejszej niż 1 ha lub w postępowaniu egzekucyjnym czy upadłościowym. W świetle dopuszczonych przez TSUE nadrzędnych względów interesu ogólnego usprawiedliwiających ograniczenie swobody przepływu kapitału, w szczególności zachowania tradycyjnej formy eksploatacji gruntów rolnych poprzez zagospodarowanie bezpośrednie, przyjęte w tym zakresie rozwiązanie wydaje się dopuszczalne. Preferując nabywanie nieruchomości rolnych przez rolników indywidualnych, nie pozbawia się bowiem prawa nabycia nieruchomości rolnych przez osoby prawne i osoby fizyczne niebędące rolnikami indywidualnymi.

\subsection{Zamieszkanie na terenie określonej gminy}

Wątpliwości co do zgodności z zasadą swobodnego przepływu kapitału budzi natomiast wymóg zamieszkiwania na terenie określonej gminy. Jak zwrócono uwagę w literaturze, ograniczenie to miało głównie na celu ochronę polskich gruntów rolnych przed wykupem przez cudzoziemców ${ }^{70}$. W związku z tym warto przypomnieć, że w orzecznictwie TSUE wymóg zamieszkania, jako jedna z przesłanek nabycia nieruchomości rolnej, był wielokrotnie poruszany w kontekście ograniczeń swobody przepływu kapitału. Co prawda wymóg zamieszkania nie jest a priori uznawany za niedopuszczalny ze swej natury $^{71}$ i choć jest to środek ograniczający swobodny przepływ kapitału,

${ }^{70}$ A. Lichorowicz, Instrumenty oddziatywania na strukture gruntowa Polski w ustawie z 11 kwietnia 2003 r. o ksztaltowaniu ustroju rolnego, „Kwartalnik Prawa Prywatnego” 2004, z. 2 , s. 402; P. Blajer, Definicja i status rolnika indywidualnego w świetle nowelizacji ustawy o ksztattowaniu ustroju rolnego, „Studia Iuridica Agraria” 2012, t. X, s. 477.

${ }^{71}$ Wyroki TSUE: z 23 września 2003 r. w sprawie C-452/01, Ospelt i Schlössle Weissenberg, EU:C:2003:493, pkt 37; z 25 stycznia 2007 r. w sprawie C-370/05, Festersen, EU:C:2007:59, pkt 26 i 33. Warto zwrócić uwagę, że w komunikacie wyjaśniającym Komisji w sprawie nabywania gruntów rolnych i prawa Unii Europejskiej, C/2017/6168 (Dz. Urz. C-350 z 18.10.2017, 
TSUE uznaje dopuszczalność jego wprowadzenia dla ochrony pewnych wartości (np. zapewnienie właściwego wykorzystywania dostępnych nieruchomości rolnych poprzez przeciwdziałanie presji na rynku nieruchomości rolnych i nabywaniu nieruchomości dla celów wyłącznie spekulacyjnych ${ }^{72}$ ), o ile jednak spełnione zostaną wymogi niedyskryminacji oraz proporcjonalności ${ }^{73}$. Poza tym, jak zaznaczono w literaturze, kryterium to budzi wątpliwości w świetle prawa do swobodnego wyboru miejsca zamieszkania, gwarantowanego w art. 52 ust. 1 Konstytucji ${ }^{74}$. Wiąże się z nim wiele problemów praktycznych (np. zamieszkiwanie na terenie gminy sąsiedniej, w której nie ma gruntów rolnych, lub zmiana miejscowego planu zagospodarowania przestrzennego, w wyniku czego nieruchomość, na której usytuowany jest budynek mieszkalny, utraci status gruntu rolnego $)^{75}$. W związku ze swobodą przepływu towarów najbardziej zasadna byłaby rezygnacja z kryterium uzyskania statusu rolnika indywidualnego, tym bardziej że dla uzyskania i posiadania tego statusu wymagane jest m.in. posiadanie odpowiednich kwalifikacji oraz osobiste prowadzenie gospodarstwa rodzinnego, z czym wiąże się konieczność przebywania na terenie gospodarstwa. Wymogi te wydają się wystarczające także dla realizacji takich dopuszczonych przez

s. 5) błędnie zinterpretowano pkt 54 z orzeczenia C-452/01 Ospelt, wyciągając z niego zupełnie odmienne wnioski, niż w rzeczywistości z niego wynikają. W komunikacie stwierdza się bowiem: „W sprawie Ospelt Trybunał wykluczył zgodność z prawem wszelkich warunków, na podstawie których wymaga się, by miejscem zamieszkania nabywcy była przedmiotowa nieruchomośc" i na poparcie tego twierdzenia przywołany został pkt 54 orzeczenia. W punkcie tym stwierdza się jednak, że co do zasady przepisy Traktatu nie wykluczają możliwości wprowadzenia regulacji krajowych uzależniających nabycie nieruchomości od uzyskania uprzedniego zezwolenia, przy czym ,uniemożliwiają one odmowę udzielania takiego zezwolenia w każdym przypadku, w którym nabywca sam nie prowadzi działalności rolniczej na gruncie wchodzącym w skład gospodarstwa i na którym nie zamieszkuje” („However, they do preclude such authorisation being refused in every case in which the acquirer does not himself farm the land concerned as part of a holding and on which he is not resident”). W kontekście pozostałej treści orzeczenia nie ma wątpliwości, że wyżej cytowane stwierdzenie nie oznacza, iż niedopuszczalne jest wprowadzenie kryterium zamieszkania dla nabycia nieruchomości rolnej, ale że niedopuszczalne jest, aby kryterium zamieszkania miało charakter bezwzględny.

72 Wyrok TSUE z 25 stycznia 2007 r. w sprawie C-370/05, Festersen, EU:C:2007:59, pkt 27 i 33.

73 Wyroki TSUE: z 23 września 2003 r. w sprawie C-452/01, Ospelt i Schlössle Weissenberg, EU:C:2003:493, pkt 34; z 25 stycznia 2007 r. w sprawie C-370/05, Festersen, EU:C:2007:59, pkt 26; z 1 czerwca 1999 r. w sprawie C-302/97, Klaus Konle, ECLI:EU:C:1999:271, pkt 40.

${ }^{74}$ A. Lichorowicz, Instrumenty oddziatywania na strukturę..., s. 402; P. Blajer, Pojęcie rolnika indywidualnego w ustawie o ksztaltowaniu ustroju rolnego, „Studia Iuridica Agraria” 2007, t. VI, s. 187. Na ryzyko naruszenia tego prawa poprzez wprowadzanie wymogu zamieszkania zwracał też uwagę TSUE. Zob. sprawa C-370/05, Festersen, EU:C:2007:59, pkt 35.

75 J. Bieluk, Ustawa o ksztaltowaniu ustroju rolnego. Komentarz, Warszawa 2016, s. 233; P. Wojciechowski, Pojęcie rolnika, w: M. Korzycka (red.), Instytucje..., s. 293. 
TSUE nadrzędnych względów interesu ogólnego usprawiedliwiających ograniczenie swobody przepływu kapitału, jak utrzymanie do celów zagospodarowania przestrzennego stałej populacji na obszarach wiejskich, lub dla zapewnienia, aby nieruchomości rolne były w większości zamieszkane i uprawiane przez ich właścicieli.

\subsection{Zgoda indywidualna}

W ustawie o kształtowaniu ustroju rolnego przewidziano, że nabycie nieruchomości rolnej może być dokonane przez podmioty inne niż rolnik indywidualny lub podmioty, w odniesieniu do których zastosowanie mają wyłączenia ustawowe (podmiotowe, przedmiotowe lub obszarowe) za zgodą dyrektora generalnego KOWR. Zgoda taka jest wydawana w drodze decyzji administracyjnej na wniosek określonych w art. 2a ust. 4 u.k.u.r. osób. Postępowanie prowadzone w sprawie wydania decyzji w tym przedmiocie jest postępowaniem administracyjnym, a decyzja wyrażająca zgodę ma charakter konstytutywny.

TSUE, uznając, że uzależnienie przeniesienia prawa własności gruntów rolnych od uzyskania uprzedniego zezwolenia administracyjnego ogranicza swobodny przepływ kapitału, jednocześnie dopuścił możliwość stosowania tego instrumentu, wskazując, że w pewnych okolicznościach system uprzedniego zezwolenia może być wręcz konieczny do osiągnięcia celów, jeśli ten sam cel nie może być osiągnięty za pomocą mniej restrykcyjnych instrumentów ${ }^{76}$. Zatem uzyskanie uprzedniego zezwolenia administracyjnego może być uzasadnione na mocy prawa $\mathrm{Unii}^{77}$. Trybunał podkreślił przy tym, że w ramach systemu uprzedniego zezwolenia nie można przyznawać swobody uznania, która może doprowadzić do tego, że właściwe organy będą z niej korzystać w sposób arbitralny oraz podejmować arbitralne decyzje. System taki ,powinien opierać się na obiektywnych, niedyskryminacyjnych i znanych wcześniej kryteriach zapewniających jego odpowiedniość, jeśli chodzi o wystarczające zakreślenie ram uznania władz krajowych" ${ }^{78}$.

Przyjęte w Polsce rozwiązanie nie jest w całości oparte na systemie uprzedniego zezwolenia, ponieważ zezwolenie jest wymagane w tych przy-

${ }^{76}$ Wyrok TSUE z 23 września 2003 r. w sprawie C-452/01, Ospelt i Schlossle Weissenberg, ECLI:EU:C:2003:493, pkt 41 i przywołane tam orzecznictwo.

${ }^{77}$ Ibidem, pkt 43-45.

${ }^{78}$ Wyroki TSUE: z 1 października 2009 r., Woningstichting Sint Servatius, C-567/07, EU:C:2009:593, pkt 35; z 10 marca 2009 r. w sprawie C-169/07, Hartlauer, ECLI:EU:C:2009:141, pkt 64 i przytoczone tam orzecznictwo. 
padkach, gdy nabywca nie jest rolnikiem indywidualnym i nie ma tu zastosowania żaden wyjątek ustawowy. Dopuszczenie możliwości nabycia nieruchomości rolnej za uprzednim zezwoleniem ma więc charakter uzupełniający w stosunku do zasady nabywania nieruchomości rolnych przez rolnika indywidualnego oraz do wyjątków ustawowych. Takie usytuowanie systemu uprzednich zezwoleń wpływa na jego ocenę w świetle zasad wynikających z orzecznictwa TSUE, a zwłaszcza na ocenę jego proporcjonalności.

Brzmienie art. 2a ust. 4 in principio u.k.u.r. pozwala uznać, że mamy do czynienia z decyzją związaną, czyli przeciwieństwem swobodnego uznania, tj. sam fakt jej podjęcia i treść są ściśle określone przepisami prawa, a proces ocenny organu administracyjnego ograniczony jest do minimum: polega na sprawdzeniu, czy wystąpiły przesłanki do wydania decyzji ${ }^{79}$. W przypadku zatem, gdy organ stwierdzi, że przesłanki określone w poszczególnych punktach zostały spełnione, nie ma podstaw do odmowy wydania zgody na nabycie nieruchomości rolnej. Jak pokazuje praktyka, zdecydowana większość wniosków składanych do dyrektora generalnego KOWR rozpatrywanych jest pozytywnie (ok. 90\%), w przypadku części wniosków wydawana jest decyzja o umorzeniu postępowania (głównie ze względu na bezprzedmiotowość), a jedynie nieznaczna część rozpatrywana jest negatywnie ${ }^{80}$. Zarówno usytuowanie systemu uprzednich zezwoleń, oparcie go na decyzjach związanych, jak i praktyka stosowania tych przepisów pozwalają uznać, że rozwiązanie to nie narusza nadmiernie zasady swobodnego przepływu towarów, a wręcz przeciwnie - to właśnie zgody indywidualne łagodzą rygoryzm zasady nabywania nieruchomości rolnych przez rolników indywidualnych. Warto podkreślić, że związany z uzyskaniem zgody dyrektora generalnego KOWR obowiązek prowadzenia działalności rolniczej na nabywanej nieruchomości oraz wymóg niedopuszczenia do nadmiernej koncentracji znajdują uzasadnienie w dopuszczonych przez TSUE nadrzędnych względach interesu ogólnego usprawiedliwiających ograniczenie swobody przepływu kapitału.

${ }^{79}$ Wyrok WSA w Gdańsku z 16 października 2019 r., I SA/Gd 246/19.

${ }^{80}$ W 2019 r. do KOWR wpłynęło łącznie 13742 (19 874 w 2018 r. i 17716 w 2017 r.) wniosków o wyrażenie zgody na nabycie nieruchomości rolnych (o łącznej powierzchni 50,8 tys. ha). W 2019 r. wydano łącznie 13870 decyzji administracyjnych (wobec 18581 decyzji w $2018 \mathrm{r}$. i 15176 decyzji w 2017 r.), które dotyczyły nieruchomości rolnych o powierzchni 49 278,13 ha, z tego: 12177 decyzji pozytywnych (dla nieruchomości o powierzchni $40903,40 \mathrm{ha}$ ), czyli 88\% (w 2018 r. 17152 decyzji, co stanowi 92,3\% i 13975 w 2017 r.), 1536 decyzji o umorzeniu postępowania (w 2018 r. 1136, a w 2017 r. 955), 157 decyzji negatywnych (w 2018 r. 293, w 2017 r. 246). Zob. Sprawozdanie z działalności Krajowego Ośrodka Wsparcia Rolnictwa w 2019 roku, s. 57; Sprawozdanie z działalności Krajowego Ośrodka Wsparcia Rolnictwa w 2018 roku, s. 53; Sprawozdanie z działalności Krajowego Ośrodka Wsparcia Rolnictwa w 2017 roku, s. 59, https:// www.kowr.gov.pl/analiza/sprawozdania [dostęp: 8.09.2020]. 


\section{Zasada prowadzenia gospodarstwa rolnego na nabytej nieruchomości w świetle zasady swobodnego przepływu kapitału}

Nie budzi wątpliwości także wprowadzona art. 2b u.k.u.r. zasada, że nabywca nieruchomości rolnej jest zobowiązany przez 5 lat prowadzić gospodarstwo rolne, w skład którego weszła nabyta nieruchomość rolna, oraz zakaz zbywania nieruchomości w tym okresie, co stanowi ograniczenie swobodnego przepływu kapitału w rozumieniu art. 63 TFUE, gdyż zniechęca potencjalnych nabywców nieruchomości rolnych. Takim ograniczeniem jest tym bardziej wymóg osobistego prowadzenia tego gospodarstwa przez nabywcę będącego osobą fizyczną oraz zakaz zbywania i oddawania nabytej nieruchomości w posiadanie.

Dokonując oceny tego rozwiązania poprzez wypracowany w orzecznictwie TSUE test, można wskazać, że nie ma podstaw do uznania, iż rozwiązanie to jest dyskryminacyjne wobec obywateli innych państw członkowskich. Co do nadrzędnych względów interesu ogólnego usprawiedliwiających ograniczenie swobody przepływu kapitału TSUE uznał, że uregulowania krajowe mogą ograniczać swobodny przepływ kapitału ze względu na cele, takie jak zachowanie eksploatacji gruntów rolnych poprzez zagospodarowanie bezpośrednie oraz zamieszkiwanie i uprawianie nieruchomości rolnych w większości przez ich właścicieli ${ }^{81}$. Dopuścił też takie cele, jak zachowanie rozdziału własności ziemskiej w sposób pozwalający na prawidłowy rozwój upraw ${ }^{82}$. Wprowadzenie wymogu prowadzenia gospodarstwa rolnego, w skład którego wejdzie nabywana nieruchomość rolna, oraz prowadzenia go osobiście w przypadku osoby fizycznej, jak również zakaz zbywania i oddawania w posiadanie ma zatem uzasadnienie w celach dopuszczonych przez TSUE, skutkuje bowiem zachowaniem eksploatacji gruntów rolnych poprzez zagospodarowanie bezpośrednie oraz uprawianiem ich przez ich właścicieli w sposób trwały.

Do rozważenia pozostaje natomiast to, czy przyjęte rozwiązanie prowadzi do tych celów i czy nie wykracza poza zakres konieczny do ich osiągnięcia. Ocena w tym zakresie wymaga uwzględnienia przyjętych wyjątków od tej zasady. Ich zakres jest szeroki, ale nie został wśród nich uwzględniony wyją-

${ }^{81}$ Wyroki TSUE: z 25 stycznia 2007 r. w sprawie C-370/05, Festersen, ECLI:EU:C:2007:59, pkt 27-28; z 6 marca 2018 r. w sprawie C-52/16 i C-113/16, SEGRO i Horváth, ECLI:EU:C:2018:157, pkt 82.

82 Wyroki TSUE: z 23 września 2003 r. w sprawie C-452/01, Ospelt i Schlössle Weissenberg, ECLI: EU:C:2003:493, pkt 39; z 6 marca 2018 r. w sprawie C-52/16 i C-113/16, SEGRO i Horváth, ECLI:EU:C:2018:157, pkt 83. 
tek, którego brak przesądził w jednym z orzeczeń TSUE o uznaniu regulacji krajowej za niedopuszczalną. Nie została bowiem dopuszczona możliwość prowadzenia gospodarstwa rolnego na nabytej nieruchomości rolnej przez dzierżawcę. W wyroku w sprawie Ospelt TSUE odniósł się do określonego krajowego środka ograniczającego zakup gruntów rolnych w celu zachowania rolniczego użytkowania gruntów. Zgodnie z prawem austriackim na zakup gruntów rolnych zezwalano jedynie, gdy np. nabywca zobowiązał się do osobistej uprawy tych gruntów. W sprawie stanowiącej podstawę do zadania pytania prejudycjalnego odmówiono wydania zezwolenia, mimo że nabywca (osoba prawna) zgodził się na dalsze wydzierżawianie działek rolnych tym samym rolnikom co poprzednio. TSUE uznał, że obowiązek osobistego prowadzenia gospodarstwa jako wymóg przy nabywaniu gruntów rolnych jest nieproporcjonalny do zakładanego celu, ponieważ ogranicza możliwość oddawania gruntów w dzierżawę rolnikom, którzy nie posiadają własnych środków na ich nabycie. Cel ten można osiągnąć za pomocą środków mniej ograniczających, tj. przez uzależnienie nabycia od udzielenia przez nabywcę gwarancji, że grunt pozostanie w użytkowaniu rolniczym ${ }^{83}$.

Odnosząc się do przyjętego w ustawie o kształtowaniu ustroju rolnego rozwiązania, należy zauważyć, że zawiera ono wymóg prowadzenia przez nabywcę gospodarstwa rolnego, w skład którego ma wchodzić nabyta nieruchomość rolna przez okres 5 lat, a w przypadku osoby fizycznej - wymóg osobistego prowadzenia gospodarstwa, oraz zawiera zakaz zbywania i oddawania w tym okresie w posiadanie nabytej nieruchomości rolnej, a jednocześnie dopuszcza się możliwość zbycia lub oddania w tym okresie nabytej nieruchomości w posiadanie osoby trzeciej za zgodą dyrektora generalnego KOWR, o ile będzie to uzasadnione ważnym interesem nabywcy nieruchomości rolnej lub interesem publicznym (art. 2 b ust. 3 u.k.u.r.). Wymóg osobistego prowadzenia gospodarstwa rolnego nie ma zatem charakteru bezwzględnego i w drodze decyzji może być wyłączony. Jak pokazuje praktyka, większość decyzji wydawanych na wniosek nabywcy rozpatrywana jest pozytywnie ${ }^{84}$.

Przesłanką wyrażenia zgody na oddanie nieruchomości rolnej w posiadanie osobie trzeciej jest jednak ,ważny interes nabywcy nieruchomości rolnej

${ }^{83}$ Wyrok TSUE z 23 września 2003 r. w sprawie C-452/01, Ospelt i Schlössle Weissenberg, ECLI:EU:C:2003:493, pkt 49-53.

${ }^{84}$ W 2019 r. do KOWR wpłynęło 1101 wniosków o wyrażenie zgody, z tego: 1054 wnioski na wcześniejsze zbycie nieruchomości rolnych, 47 wniosków na oddanie nieruchomości rolnej w posiadanie innym podmiotom. Wydanych zostało 431 rozstrzygnięć, z tego: 349 decyzji pozytywnych, 10 decyzji negatywnych, 27 decyzji o umorzeniu postępowania, 45 spraw zakończono w inny sposób niż wydanie decyzji administracyjnej (np. postanowieniem o odmowie wszczęcia postępowania). Zob. Sprawozdanie z działalności Krajowego Ośrodka Wsparcia Rolnictwa w 2019 roku, s. 67, https://www.kowr.gov.pl/analiza/sprawozdania [dostęp: 8.09.2020]. 
lub interes publiczny", nie przewiduje się natomiast przesłanki w postaci oddania nieruchomości rolnej w posiadanie osobie trzeciej, która włączy ją w prowadzone przez siebie gospodarstwo rolne. Brak takiego przepisu nie wyklucza wprawdzie tego, aby dyrektor generalny KOWR przy rozpatrywaniu wniosku o wyrażeniu zgody na oddanie nieruchomości w posiadanie osobie trzeciej przed upływem 5 lat brał pod uwagę to, w jakim celu i jakiej osobie nieruchomość ta będzie oddawana w posiadanie (co ma uzasadnienie w art. 1 ust. 1 pkt 3 u.k.u.r. ), jednak nie może to być samodzielna przesłanka wyrażenia takiej zgody. Podstawą wyrażenia zgody pozostaje bowiem wykazanie przez wnioskodawcę ważnego interesu bądź uzasadnienie jej interesem publicznym. De lege ferenda zasadne byłoby dodanie w omawianym przepisie jako odrębnej przesłanki wyrażenia zgody na oddanie nieruchomości w posiadanie osobie trzeciej, obok ważnego interesu nabywcy i interesu publicznego, także celu, jakim jest prowadzenie działalności rolniczej przez osobę, której nieruchomość ta oddawana jest w posiadanie. Taka zmiana powodowałaby, iż nie byłoby istotnych wątpliwości co do zgodności przyjętego rozwiązania z prawem unijnym. Jednak także przepis w obecnym brzmieniu pozwala na wykazanie zgodności przyjętego rozwiązania z prawem unijnym, o ile praktyka wydawania zgód przez dyrektora generalnego KOWR będzie uwzględniała cel, jakim jest prowadzenie działalności rolniczej przez osobę, której nieruchomość rolna oddawana jest w posiadanie. Co więcej, dopuszczalne powinno być uzyskanie takiej zgody jeszcze przed nabyciem nieruchomości, zwłaszcza gdy nieruchomość rolna stanowi już przedmiot umowy dzierżawy, a obecny dzierżawca i nabywca są zainteresowani jej kontynuowaniem.

\section{Podsumowanie}

Ustawa o kształtowaniu ustroju rolnego zawiera wiele rozwiązań, które mogą zniechęcać do nabywania nieruchomości rolnych. Należy do nich zaliczyć przyznane KOWR prawo pierwokupu oraz prawo nabycia, a także wprowadzenie zasady nabywania nieruchomości rolnych przez rolników indywidualnych oraz wymóg prowadzenia gospodarstwa rolnego na nabywanej nieruchomości i zakaz jej zbywania przez okres 5 lat. W świetle orzecznictwa TSUE nie budzi wątpliwości to, że rozwiązania te naruszają traktatową zasadę przepływu kapitału, która nie ma jednak charakteru absolutnego, i w pewnych okolicznościach uznają za dopuszczalne wprowadzenie krajowych rozwiązań prawnych, nawet jeśli naruszają one swobodę przepływu kapitału. 
Przedstawiona analiza prowadzi do wniosku, że rozwiązania przyjęte w ustawie o kształtowaniu ustroju rolnego ograniczające obrót nieruchomościami, przy uwzględnieniu nowelizacji ustawy dokonanej w 2016 i 2019 r., nie są dyskryminacyjne dla obywateli innych państw członkowskich. Ponadto mają one uzasadnienie w takich nadrzędnych względach interesu ogólnego, jak dopuszczone przez TSUE cele: zachowanie tradycyjnej formy eksploatacji gruntów rolnych poprzez zagospodarowanie bezpośrednie oraz zamieszkiwanie i uprawianie nieruchomości rolnych w większości przez ich właścicieli ${ }^{85}$. Przyjęte rozwiązania mogą prowadzić do tych celów, a jedyna wątpliwość dotyczy tego, czy nie wykraczają one poza zakres konieczny do ich osiągnięcia, tj. czy spełniają wymóg proporcjonalności, co w szczególności dotyczy wymogu zamieszkiwania na terenie określonej gminy. Warto odnotować, że istotne znaczenie przy ocenie obowiązujących rozwiązań ograniczających obrót nieruchomościami rolnymi w Polsce w kontekście zasady swobodnego przepływu kapitału miała nowelizacja z 2019 r., wprowadzająca szereg nowych wyjątków ustawowych i porządkująca regulacje dotyczące zasad wyrażania zgody na nabycie nieruchomości rolnych.

Biorąc pod uwagę zjawiska zachodzące na rynku nieruchomości rolnych (sygnalizowane m.in. przez instytucje unijne), a także zjawiska klimatyczne (stopniowe zmiany średnich temperatur i opadów deszczu) wpływające na przydatność gruntów na różne rodzaje upraw i pastwisk ${ }^{86}$, wprowadzanie rozwiązań prawnych ograniczających obrót nieruchomościami i skutkujących naruszeniem zasady swobodnego przepływu kapitału wydaje się nieuniknione. Nie można więc wykluczyć, że w przyszłości TSUE dokona jeszcze bardziej rozszerzającej interpretacji wyjątków od zasady swobodnego przepływu kapitału.

\title{
SELECTED ASPECTS OF THE RESTRICTION OF TRADING IN AGRICULTURAL REAL ESTATE UNDER POLISH LAW IN THE CONTEXT OF THE EU PRINCIPLE OF FREE MOVEMENT OF CAPITAL
}

\author{
Summary
}

The aim of the considerations was to assess the admissibility of restrictions of trading in agricultural real estate introduced by the Act on shaping the agricultural system in the context

${ }^{85}$ Wyroki TSUE: z 25 stycznia 2007 r. w sprawie C-370/05, Festersen, ECLI:EU:C:2007:59, pkt 27-28; z 6 marca 2018 r. w sprawie C-52/16 i C-113/16, SEGRO i Horváth, ECLI:EU:C:2018:157, pkt 82.

${ }^{86}$ Climate change and food security..., s. 12. 
of the EU principle of free movement of capital. The article presents the economic and climatic phenomena that have been taking place worldwide and in the European Union in particular, which make the introduction of legal solutions limiting trading in agricultural land inevitable. The EU principle of free movement of capital is discussed, including the premises for the admissibility of restrictions of this principle. In the light of these findings, an assessment of instruments that restrict trading in agricultural real estate has been made. The analysis carried out in the article leads to the conclusion that most of the adopted solutions pass the test of admissibility of introducing restrictions that has been developed in the case law of the Court of Justice of the European Union. Some of these restrictions, however, raise doubts.

\section{LIMITI POSTI AI TRASFERIMENTI DI IMMOBILI AGRICOLI NEL DIRITTO POLACCO NEL CONTESTO DEL PRINCIPIO DELL'UE RIGUARDANTE LA LIBERA CIRCOLAZIONE DEI CAPITALI: ALCUNI ASPETTI SCELTI}

\section{Riassunto}

L'articolo si propone di esaminare, nel contesto del principio dell'UE riguardante la libera circolazione dei capitali, i limiti posti ai trasferimenti di immobili agricoli disciplinati nella legge sul regime agricolo dal punto di vista della loro ammissibilità. Nello studio sono stati presentati i fenomeni economici e climatici in atto nel mondo, e in particolare nell'UE, i quali fanno sì che l'introduzione di soluzioni legislative volte a limitare i trasferimenti di immobili agricoli sembri ormai inevitabile. In seguito, è stato discusso il principio dell'UE riguardante la libera circolazione dei capitali, comprese le condizioni secondo le quali si possono ammettere i limiti al principio stesso. Alla luce delle costatazioni formulate, si è proceduto alla valutazione degli strumenti che limitano i suddetti trasferimenti. L'analisi svolta porta a constatare che la maggior parte delle soluzioni adottate riesca a superare il test di giudizio per l'ammissibilità delle restrizioni, sviluppato positivamente nella giurisprudenza della Corte di giustizia dell’Unione europea, benché alcune di esse sollevino dubbi. 